\title{
The Realization of Complex Work of Consolidation and Exchange of Land in the Villages Divided by a Highway
}

\section{Introduction}

In Poland it is estimated that we have 3 million hectares of arable land in the patchwork of plots. In this area the largest share of land in a patchwork is observed in south-eastern Poland. Despite this, in the current Subcarpathian Voivodeship it merged only 347 villages, with a total area of 278440 hectares, which represents only $15.6 \%$ of the total area of the Subcarpathian Voivodeship [1].

Produced in this part of Poland the patchwork of plots, it has a very small surface parcels and their dispersal. The average farm in the Subcarpathian Voivodeship consists of a few to several plots of land, registration of which don't exceed 0.30 hectares [27]. These plots are often misshapen in the lowlands very elongated and without directions. How to show a detailed study [18] in the villages of the Subcarpathian Voivodeship percentage rate of lack of access to plots ranges from $50-70 \%$ of the total number of plots in the village.

According to the analyzes [27] it is estimated that in the Subcarpathian Voivodeship about 690 thousand hectares (73\%) of the total agricultural land needs consolidation. In fact, this condition is deteriorating highway mileage through the village, which is a way of representing the most significant nerve of socio-economic, cultural and interpersonal ties. However, it is a foreign element in the landscape of villages, destroying the communication system between registration plots and habitat, as well as functional and spatial relationships between the villages. That does not mean that the construction of motorways in Poland is not the most important project bringing closer city and state. However, its linear nature covers hundreds of kilometers and as the most important investment cuts through a vast number of plots of many of their owners having a negative impact on the environment.

* Rzeszów School of Engineering and Economics, Department of Cadastre and Geodetic Spatial Planning, Rzeszów, Poland

** University of Life Sciences in Lublin, Faculty of Production Engineering. Department of Engineering, Environmental Development and Surveying, Lublin, Poland 
Elimination of the highway negative impacts on the life and work of the rural population is the fundamental issue of surveying services in the complex work of consolidation and exchange of land. By removing this process defect in the space, keep in mind that improving the quality of life for enjoying the highway cannot hurt people living and working in the countryside.

The impact of the motorway on the environment and spatial structure of land and its development has been the subject of analysis and study before the construction of highways.

This subject was examined by Banat, Szłapa [5], Banat [4], Dzikowska [6], Hopfer, Marcinkowska [7], Noga [12-17], Przegon [20, 21], Schilbach [22, 23] Sobolewska-Mikulska [25], Wilkowski [26] and others.

The impact of the motorway on the environment and land spatial structure was analyzed on many levels. What changes have been studied in rural areas will introduce linear investment. Methodology developed motorway impact on rural areas, which should be the basis for the right location decisions, determine the appropriate compensation and implementation of local investments partially eliminate losses. No it resulted in a long-term period of stagnation in the location and construction of new highways. The need to develop the said methodology resulted in numerous studies theoretical and practical, that based on existing scientific evidence agricultural organization of rural space and the experience of countries in Western Europe, the other elements analyzed in terms of changes caused by the location and operation of highways, prior to its implementation. These works were analyzing and assessing the overall, which makes highway in space. There is no detailed analyzes and impact assessments which resulted in highway mileage, and the methodology of implementation of the comprehensive work of consolidation and exchange of land.

So far, exercised or performed work around the highway merge only affect the area, which was set in the impact assessment highway on agricultural land, forestry and human health. Dedicated in this assessment areas were located along roads, watercourses forests and other invariants field. Other rural areas are not consolidation. For such a small area applies in principle to consolidation the regulation of legal relations to land in the existing road layout direct service fields. This is only a corrective action does not solve other problems, such as the arrangement of plots on a farm [24]. As part of consolidations around the highway is not carried out exchanges of land. Yes executed works from funds that GDDKiA receives annually from the state budget, are not properly used, because the rest of the village has a large patchwork of plots and a large number of land parcels without directions.

In connection with the so-understood issue in the scientific description the methodology for the realization of complex work of consolidation and exchange of land for the village divided by the highway. 


\section{The Algorithm for Determining the Order of Undertaking Work of Consolidation and Exchange of Land in the Villages Divided by the Highway}

Based on our detailed analysis and assessment of the destruction of spatial systems of land, investment and development of rural areas [1-3] and the literature provides a method for the realization of complex works merging and exchange of land for the village divided by the highway. In the process of implementation of the comprehensive work of consolidation and exchange land they adopted the idea of the total works out of the office and at the request of the parties. This proposal stems from the fact that research carried out by Balawejder [1-3]. The limitation only to merge with the office, included in the assessment made of the motorway on agricultural land, forests and human health, doesn't meet the main objective to improve the work and life of farmers and villagers crossed by the highway.

Consolidation with the office around highways include very different surface areas depending on the intersection of the village of extending the motorway. This makes that you can't reasonably be comprehensively carry out consolidation and exchange of land.

Such an approach in the current practice consolidations around the highway when they do not cover the whole village is unrealized only on formal grounds (two different sources of funding) rather than substantive. But wanting to pursue adopted the idea, the developed method, you must first divided by the highway in the villages to carry out reliable information concerning the rank and importance consolidations and exchanges of land in the whole village. Such training should be carried out in villages where entire village consolidation is justified and stems from disturbances (destruction) of the spatial structure of land resulting from the motorway.

To determine the degree of destruction of the spatial structure of land in the villages divided by the highway algorithm was developed which specifies the order to undertake consolidation and exchange land in the villages divided by the highway. The algorithm is shown in Figure 1.

As shown in Figure 1, in order to determine the hierarchy to undertake consolidation and exchange it is necessary to identify appropriate diagnostic variables [9] directly related to the conduct of the highway through the test village.

Research has shown [2] initially to calculations the 44 variables (features), setting out the direct and indirect impact of the motorway on the location of spatial development village land divided by the highway. In order to clearly present the characteristics directly and indirectly determining the location of the motorway impact on land use village land has been divided by the highway grouping of variables, as shown in Table 1. 


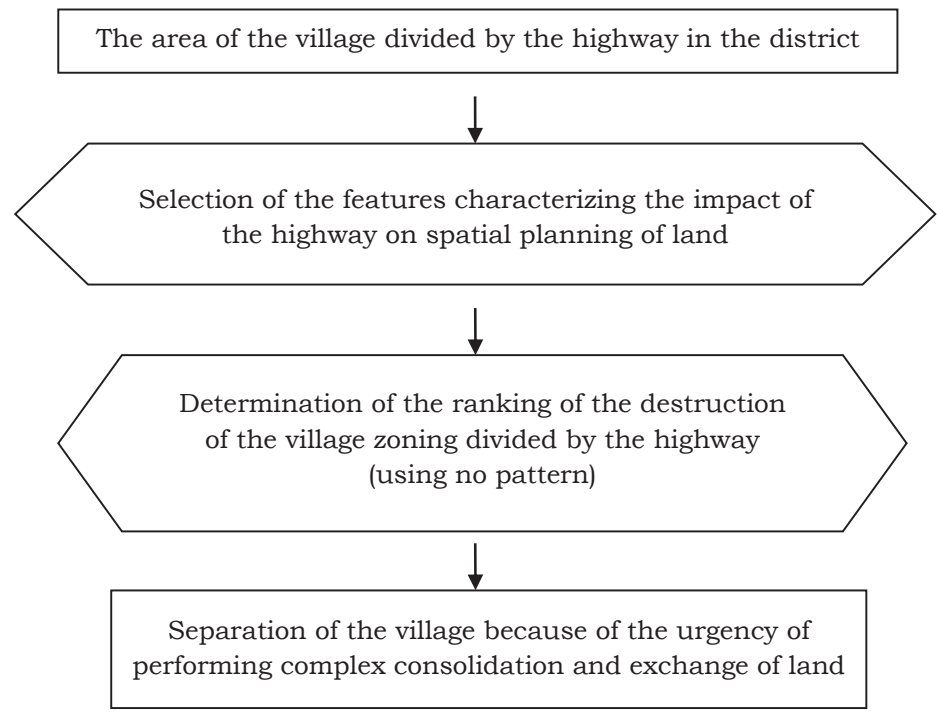

Fig. 1. The algorithm for determining the order of undertaking consolidation and exchange land in the villages divided by the highway

Table 1. Comparison of variables adopted for testing describing the analyzed area in separate groups

\begin{tabular}{|c|c|c|c|c|}
\hline No. & $\begin{array}{l}\text { Group of variables } \\
\text { taken for testing }\end{array}$ & $\begin{array}{l}\text { Variable group directly / } \\
\text { indirectly linked with the } \\
\text { course of the highway }\end{array}$ & $\begin{array}{l}\text { Number of } \\
\text { variables } \\
\text { (features) }\end{array}$ & $\begin{array}{l}\text { The percentage of variables } \\
{[\%]}\end{array}$ \\
\hline 1 & land use & indirectly & 9 & 20.5 \\
\hline 2 & ownership of land & indirectly & 6 & 13.6 \\
\hline 3 & $\begin{array}{l}\text { land } \\
\text { fragmentation }\end{array}$ & directly & 5 & 11.4 \\
\hline 4 & $\begin{array}{l}\text { destruction of the } \\
\text { highway }\end{array}$ & directly & 14 & 31.8 \\
\hline 5 & $\begin{array}{l}\text { consolidation and } \\
\text { exchange of land }\end{array}$ & indirectly & 4 & 9.1 \\
\hline 6 & \begin{tabular}{|l|} 
patchwork of \\
individual plots
\end{tabular} & directly & 6 & 13.6 \\
\hline \multicolumn{3}{|l|}{ Total: } & 44 & 100.0 \\
\hline
\end{tabular}

In the first group "land use" Listed nine variables, which represent $20.5 \%$ of all admitted to the study. Another specified group is "ownership of land" in which there are six characteristics that represent $13.6 \%$ of the total. The third group is directly related to the conduct of the highway is "land fragmentation" of five attributes which constitute $11.4 \%$ of all accepted to study variables. In the fourth group of "destruction of the highway" directly related to the conduct of the highway is 14 features occupying the largest share up to $31.8 \%$ of the total variable admitted to the study. The fifth group is "consolidation and exchange land" with a number of 
features 4 , which represents $9.1 \%$ of all accepted to study variables. The last group is directly related to "patchwork of individual plots" in which there are six characteristics that represent $13.6 \%$ of all the variables taken for testing.

To create the ranking destruction of the village the spatial development should be taken only variable determining a direct impact location on the highway spatial development village land divided by the highway [3]. It is a 25 variables belonging to three groups: the fragmentation of land, destruction of the motorway and private land patchwork. A detailed list of these variables determining a direct impact location on the highway spatial development village land divided by the highway are presented in Table 2.

Table 2. The list of variables determining the direct impact of the motorway location on the spatial development of villages divided by the highway

\begin{tabular}{|c|c|c|}
\hline No. & $\begin{array}{l}\text { Group of features } \\
\text { taken for testing }\end{array}$ & Features \\
\hline 1 & \multirow{5}{*}{$\begin{array}{l}\text { land } \\
\text { fragmentation }\end{array}$} & the total number of plots in the village \\
\hline 2 & & the number of parcels in the individual sector \\
\hline 3 & & the average size of plots in the village \\
\hline 4 & & the average area of plots in the individual sector \\
\hline 5 & & number of owners in the individual sector \\
\hline 6 & \multirow{14}{*}{$\begin{array}{l}\text { destruction of the } \\
\text { highway }\end{array}$} & percent of the area section of the motorway in the village \\
\hline 7 & & percent share of the number of plots within the highway \\
\hline 8 & & percent of the cut off area of the highway north from the highway \\
\hline 9 & & percent of the cut off area of the highway south from the highway \\
\hline 10 & & percent share of the area of villages cut from the habitat by the highway \\
\hline 11 & & the number of cut roads \\
\hline 12 & & the number of cut drainage ditches \\
\hline 13 & & the number of cut water supplies \\
\hline 14 & & the number of cut gas pipelines \\
\hline 15 & & the number of cut telecommunication lines \\
\hline 16 & & the number of cut sewer networks \\
\hline 17 & & the number of cut energy networks \\
\hline 18 & & the number of residential buildings to be demolished \\
\hline 19 & & the number of farm buildings to be demolished \\
\hline 20 & \multirow{6}{*}{$\begin{array}{l}\text { patchwork of } \\
\text { individual plots }\end{array}$} & percent share of the number of plots of out-of-village owners \\
\hline 21 & & percent share of the area of plots of out-of-village owners \\
\hline 22 & & percent share of the number of out-of-village owners \\
\hline 23 & & percent share of the number of plots of internal patchwork of plots \\
\hline 24 & & percent share of the area of plots of internal patchwork of plots \\
\hline 25 & & percent share of the number of internal patchwork of plots \\
\hline
\end{tabular}


Then, using the method without pattern, based on the procedure unitarisation zero without reducing the set of variables (without reduction API), we can examine in what order we go into this work in the village of divided by the highway.

This method is very popular in socio-economic research, it is widely described in the literature. The unitarisation zero procedure is described in detail in the monograph by Kukuła [10]. A detailed technical description of the determination of synthetic measure using an Excel spreadsheet can be found in the book by Hydzik and Sobolewski [8]. In accordance with the procedure unitarisation zero are created every year rankings municipalities in the provinces. Also, based on this method a ranking urgency of carrying out works land consolidation and exchange [11]. To complete the ranking of the village due to the impact location of the motorway on land use village land crossed by the highway, we must transform the diagnostic value of the output variable having the nature of stimulants. This is done using the formula:

$$
x_{i}^{U}=\frac{x_{i}-x_{\min }}{x_{\max }-x_{\min }}
$$

and for destimulants:

$$
x_{i}^{u}=\frac{x_{\max }-x_{i}}{x_{\max }-x_{\min }}
$$

where:

$$
\begin{aligned}
& x_{i}^{U} \text { - value unitarisation } i \text {-th component of the variable, } \\
& x_{i} \text { - value not unitarisation } i \text {-th component of the variable, } \\
& x_{\max } \text { - the maximum value of the variable, } \\
& x_{\min } \text { - the minimum value of the variable. }
\end{aligned}
$$

The value of the characteristics for a given object is calculated "distance" from the object at a minimum for stimulants (maximum for destimulants), which is then expressed in \% chasm for a given trait. In this way an object with the optimal value of the basic features of the application of the procedure unitarisation assigned a value of $100 \%$, while the object worst $0 \%$. After the procedure unitarisation for all characteristics for each object synthetic indicator is calculated as the average of all transformed variables. The thus obtained synthetic indicator is a stimulant and also includes the range of $0-100 \%$, although the extreme may not be achieved. The resulting synthetic indicator - the percentage cut for the village of motorway - determines the degree of destruction of the spatial structure of the village. In decreasing the percentage of synthetic measure, destruction of agricultural structure intersected the highway is reduced. This fact fully confirms the route of the motorway through the village [19]. 


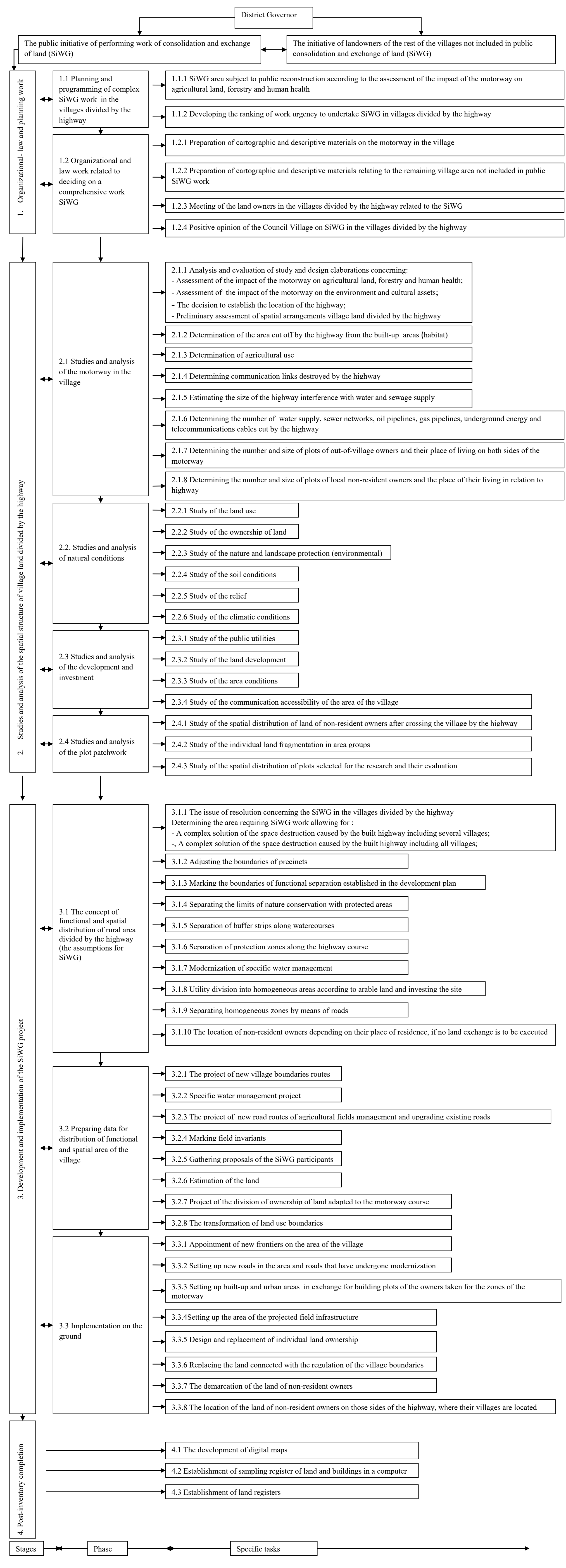

Fig. 2. The realization of the work of consolidation and exchange of land (SiWG) in the villages divided by the highway 
Villages establishing themselves as the last in the ranking do not require reconstruction of the spatial structure by merging and exchange of land only. While the villages of synthetic meter high have the greatest destruction of agricultural production space. The court therefore finds that most reflect the impact of motorway location for the development of rural land crossed by the highway is reflected in the rankings for variables directly related to the conduct of the highway without using the API methods [2].

District governor, having an established a hierarchy of making this work in villages divided by the highway, should be carried out with resident meetings where information would be communicated on the need for implementation of complex consolidations and exchange their land. The more so that the merging and exchange of land areas divided by the highway should be carried out not only with the office (at the expense of the General Directorate for National Roads and Motorways), but also at the request of land owners the rest of the village is not covered by merging and exchange of land around the highway.

\section{Methods of Performing Consolidation and Exchange of Land}

The correct implementation of comprehensive consolidations and exchange of land (SiWG), and thus improve the working and living conditions of rural residents, ensures proper methodology for their execution. In order to properly carry out the work of consolidation and exchange land provides a method for the realization of complex works SiWG divided into stages, phases and tasks, which spatially schematic Figure 2.

As shown in Figure 2, the developed method realization of complex works SiWG divided into four steps comprising:

1. Organizational-law and planning work.

2. Studies and analysis of the spatial structure of village land divided by the highway.

3. Development and implementation of the SiWG project.

4. Post-inventory completion.

These stages of land consolidation works have been divided into phases, endearing planning and programming of work, studies and analyzes descriptive and mapping the spatial structure of land, to enable the development of guidelines for the project merge, geodetic implementation of the detailed design consolidation and as inventory post-completion.

Each phase has certain specific tasks whose technological and technical implementation allows for the execution of the complex work of consolidation and exchange of land.

In the first stage, it is proposed to develop a hierarchy of urgency SiWG and comprehensive work programs to consolidation and exchange of land. For this 
purpose should be carried out organizational work associated with deciding conducting comprehensive work to consolidation and exchange of land.

The second most important step is the preparation of studies and analyzes on the motorway in the village, natural conditions, development and investment and prepare analyzes the patchwork of plots.

In the implementation of the third stage of the need to comply with the concept of functional and spatial distribution of rural area intersected the highway, preparing data for distribution of functional and spatial area and implementation in the field.

The fourth stage of the work, including as inventory post-completion is the basis for founding an information database of land and buildings (EGiB) and land registry database $(\mathrm{KW})$. This solution is one of the tasks of integrating databases $\mathrm{EGiB}$ and KW, which will operate the Integrated Information System for Real Estate.

\section{Summary}

A conducted analysis and assessment of the spatial structure of private land, in villages crossed by a highway, highlighted her very much defect. These defective accumulate over the centuries and resulted from legal and socio-economic conditions. Which runs through the village of motorway has further destruction in investing, land development in the already defective the patchwork of plots.

The conducted study reveals the following observations, comments and conclusions:

1. Implementation of comprehensive works consolidation and exchange of land the village divided by the highway should be taken in accordance with the size of the defect in the existing and occurred chess of land.

2. In order to determine the urgency of making the work of consolidation and exchange land work without a standard method was used, based on the procedure unitarisation zero without reducing the set of variables (without reduction API).

3. Having established a hierarchy of urgency to undertake consolidation and exchange land in the villages divided by the highway should be carried out with residents a wide and constructive action that promotes the need for their implementation.

4. To ensure the proper implementation of the work of consolidation and exchange of land developed a comprehensive methodology for their implementation.

In summary, the destruction of that size made in the use of space of rural and acting on them, a large chess of land can be wound in a different way than before uniting work is consolidation land. The completed studies have shown the possibility of removing the defective developed the methodology implementation of complex works to consolidation in close connection with the exchange of land. 


\section{References}

[1] Balawejder M.: Hierarchizacja potrzeb prac scalenia i wymiany gruntów we wsiach podzielonych autostrada. [in:] Dudzińska M., Kocur-Bera K. (red.), Ksztattowanie obszarów wiejskich z uwzględnieniem parametrów przestrzennych, Kraków 2015, pp. 8-29.

[2] Balawejder M., Bielska A., Cymerman R., Gniadek J., Mazur A., Ogryzek M., Pijanowski J., Sobolewska-Mikulska K., Stańczuk-Gałwiaczek M., Taszakowski J.: Analiza rozwoju scaleń i wymian gruntów w latach 1923-2013 na terenie województwa podkarpackiego. [in:] Sobolewska-Mikulska K. (red.), Wspótczesne scalenia gruntów w kształtowaniu granic rolniczej przestrzeni produkcyjnej, Warszawa 2015, pp. 49-66.

[3] Balawejder M., Buśko M., Cellmer R., Juchniewicz-Piotrowska K., Leń P., Mika M., Szczepankowska K., Wójciak E., Wójcik-Leń J., Źróbek S.: Sposoby pozyskania gruntów pod budowe autostrady oraz jej wpływ na zagospodarowanie i zainwestowanie rolniczej przestrzeni produkcyjnej. [in:] Balawejder M., Mika M. (red.), Aktualne problemy gospodarki nieruchomościami w Polsce na tle przemian organizacyjno-prawnych, Rzeszów 2015, pp. 92-124.

[4] Banat J.: Zmiany struktury gospodarstw jako skutek budowy autostrady. Sesja Naukowa, z. 68, Zeszyty Naukowe, nr 353, Akademia Rolnicza, Kraków 1999, pp. 65-72.

[5] Banat J., Szłapa A.: Skutki przestrzenne budowy autostrady na terenach o rozdrobnionej strukturze gospodarstw rolnych. Sesja Naukowa, z. 59, Ogólnopolska Konferencja Naukowa nt. Wielofunkcyjny rozwój obszarów wiejskich, Zeszyty Naukowe, Akademia Rolnicza, Kraków 1998, pp. 115-122.

[6] Dzikowska T.: Ocena oddziaływania autostrady na organizacje rolniczej przestrzeni produkcyjnej. Acta Scientiarum Polonorum, vol. 5 (1-2), 2006, pp. 17-38.

[7] Hopfer A., Marcinkowska I.: Modelowe (schematyczne) rozwiazania redystrybucji przestrzennej gruntów „poruszonych" przez autostradę. [in:] Metodyka oceny oddziaływania autostrady na grunty rolne i leśne: sesja naukowa z okazji nadania tytułu doktora honoris causa Akademii Rolniczej im. H. Kołłataja w Krakowie prof. zw. dr hab. inż. Andrzejowi Hopferowi, AR. SWoT, Kraków 1997, pp. 31-38.

[8] Hydzik P., Sobolewski M.: Komputerowa analiza danych społeczno-gospodarczych. Wyd. Politechniki Rzeszowskiej, Rzeszów 2007.

[9] Jajuga K.: Statystyczna analiza wielowymiarowa. WN PWN, Warszawa 1993.

[10] Kukuła K.: Metoda unitaryzacji zerowanej. WN PWN, Warszawa 2000.

[11] Dudzińska M., Jasińska E., Kocur-Bera K., Leń P., Preweda E., Sajnóg N., Sobolewska-Mikulska K., Steinsholt H., Walacik M., Wójcik J.: Directions for Land Management in Rural Areas. Nacionalna knjižnica, Zagreb, Croatia 2014, pp. 43-45. 
[12] Noga K.: Wpływ autostrady na układ przestrzenno-gospodarczy wsi południowo-wschodniej Polski. Sesja Naukowa, z. 72, Zeszyty Naukowe, nr 365, Akademia Rolnicza, Kraków 2000, pp. 273-282.

[13] Noga K.: Sposób realizacji szczegółowego projektu scalenia gruntów w zasięgu oddziaływania autostrad. Sesja Naukowa, z. 68, Zeszyty Naukowe, nr 353, Akademia Rolnicza, Kraków 1999, pp. 311-318.

[14] Noga K.: Metodyka pozyskania nieruchomości pod budowę autostrad. Zeszyty Naukowe, z. 59, Akademia Rolnicza, Kraków 1998, pp. 359-366.

[15] Noga K.: Wykorzystanie katastru nieruchomości w procesie przygotowania budowy autostrad. [in:]. Geodezja inżynieryjna i kataster w gospodarce narodowej: materiały z międzynarodowego sympozjum, Zeszyty Naukowe Politechniki Rzeszowskiej. Budownictwo i Inżynieria Środowiska, z. 29, 1998, pp. 329-334.

[16] Noga K.: Prace urzadzenioworolne w procesie budowy autostrad. [in:] Zagospodarowanie przestrzenne a urządzanie obszarów wiejskich: XI Sympozjum Naukowe "Nowe tendencje w teorii i praktyce urządzania obszarów wiejskich", Wrocław-Polanica Zdrój 17-19.09.1997 r., Zeszyty Naukowe Akademii Rolniczej we Wrocławiu. Konferencje, t. 14, Wyd. Akademii Rolniczej, Wrocław 1997, pp. 165-171.

[17] Noga K.: Kryteria określania potrzeb przeprowadzania prac scaleniowych $i$ wymian gruntów w zasięgu oddziaływania autostrady (na przykładzie wybranego odcinka Kraków-Tarnów). [in:] Metodyka oceny oddziaływania autostrady na grunty rolne i leśne: sesja naukowa z okazji nadania tytułu doktora honoris causa Akademii Rolniczej im. H. Kołtataja w Krakowie prof. zw. dr hab. inż. Andrzejowi Hopferowi, AR. SWoT, Kraków 1997, pp. 79-84.

[18] Noga K., Błaż K.: Sposób oceny szachownicy gruntów w wybranych wsiach powiatu brzozowskiego. Infrastruktura i Ekologia Terenów Wiejskich, nr 03, 2011, pp. 217-226.

[19] Piotrowska M.: Analiza przebiegu autostrady A-4 w województwie podkarpackim. [in:] Wielokierunkowość badań w rolnictwie i leśnictwie: monografia 2008, Wydawnictwo Uniwersytetu Rolniczego, Kraków 2008.

[20] Przegon W.: Autostrady - nierealność roku 2010. [in:] Metodyka oceny oddziaływania autostrady na grunty rolne i leśne: sesja naukowa z okazji nadania tytułu doktora honoris causa Akademii Rolniczej im. H. Kotłataja w Krakowie prof. zw. dr hab. inż. Andrzejowi Hopferowi, AR. SWoT, Kraków 1997, pp. 85-90.

[21] Przegon W.: Za, a nawet przeciw budowie autostrad. [in:] Autostrada w krajobrazie polskiej wsi, nr 7, Politechnika Krakowska, Kraków, pp. 86-101.

[22] Schilbach J.: Wykorzystanie oceny oddziaływania autostrady na grunty rolne i leśne do opracowania ogólnego projektu scalania gruntów położonych w jej sasiedztwie. [in:] Zagospodarowanie przestrzenne a urządzanie obszarów wiejskich: XI Sympozjum Naukowe "Nowe tendencje w teorii i praktyce urządzania obszarów wiejskich", Wrocław-Polanica Zdrój 17-19.09.1997 r., Zeszyty Naukowe Akademii Rolniczej we Wrocławiu. Konferencje, t. 14, Wyd. Akademii Rolniczej, Wrocław 1997, pp. 165-171. 
[23] Schilbach J.: Podstawowe ustalenia konieczne do opracowania oceny wptywu autostrady na grunty rolne i leśne. [in:] Metodyka oceny oddziaływania autostrady na grunty rolne i leśne: sesja naukowa z okazji nadania tytułu doktora honoris causa Akademii Rolniczej im. H. Kołtataja w Krakowie prof. zw. dr hab. inż. Andrzejowi Hopferowi, AR. SWoT, Kraków 1997, pp. 91-98.

[24] Sobolewska-Mikulska K.: Możliwości wykorzystania scaleń infrastrukturalnych w procesie przebudowy struktury przestrzennej obszarów wiejskich. Infrastruktura i Ekologia Terenów Wiejskich, nr 01/II, 2012, pp. 41-51.

[25] Sobolewska-Mikulska K.: Podstawy ekologiczno-krajobrazowe zwiazane z budowa autostrad. Prace Naukowe - Politechnika Warszawska. Geodezja, z. 33, 1995, pp. 52-67.

[26] Wilkowski W.: Wielokryterialna metoda oceny wptywu autostrady na gospodarstwa rolne. Prace Naukowe - Politechnika Warszawska. Geodezja, z. 33, 1995, pp. 5-19.

[27] Strategia rozwoju województwa podkarpackiego na lata 2007-2020. [on-line:] www.podkarpackie.pl/attachments/article/2634/strategia-rozwoju-wojewodztwa-podkarpackie-2020.pdf [access: March 2016]. 